\title{
Role of calcium bio-minerals in regenerative medicine and tissue engineering
}

\begin{abstract}
Present review article emphasize role of biominerals in regenerative medicine and tissue engineering. Among all biominerals calcium is essential for body growth and development. It also performs many fundamental functions in cellular metabolism. Inside cell organic matrix is calcified by calcium phosphate minerals. It also embeds bone cells which participate in the maintenance and organization of bone. This article also emphasizes use of hydroxyapatite a natural mineral used as a bone-building supplement with superior absorption in comparison to calcium. It also explains use of scaffolds that mimic the structure and composition of bone tissue and cells. It also signifies use of HAc microparticles or microparticles loaded with PL, superparamagnetic iron oxide nanoparticles, composite scaffolds of nano-hydroxyapatite (nHAp) and silk fibroin (SF) in bone regeneration mainly in osteoregenerative therapy. For better and successful bone regeneration there is a need to develop low cost sintered hydroxyfluorapatite discs to support cellular proliferation and colonization, tailored mineralization, cell and drug delivery. All adhesion components should show low immunoreactivity and high biocompatibility with natural bone tissues. There is an essential need to make new biocompatible materials for scaffolding, biominerals and cementing formulations for regeneration of bones, cranio-maxillofacial, dental and orthopedic surgery.
\end{abstract}

Keywords: regenerative medicine, silk fibroin, osteoregenerative therapy, ecm
Volume 2 Issue 6 - 2017

Ravi Kant Upadhyay

Department of Zoology, DDU Gorakhpur University, India

Correspondence: Ravi Kant Upadhyay, Department of Zoology, DDU Gorakhpur University, Gorakhpur, 273009, UP, India,Email rkupadhya@yahoo.com

Received: April 24, 2017| Published: May 30, 2017

\section{Introduction}

Human body needs minerals as micronutrients because these are required to perform various biochemical functions which are necessary for life. Body organs are composed of various tissues and cells and possess micro elements in ECM which perform structural functions and provide stiffness to the cytoskeleton, bones, muscles and cartilages. Plants receive these minerals from soil and all organisms including man rely on plants. Another source of mineral nutrients is drinking water. Most required minerals for human body are calcium, phosphorous, potassium, sodium and magnesium. Trace elements are also required by micrograms for metabolism. Among trace elements iron, zinc, cobalt, copper, manganese, molybdenum, iodine and selenium are specifically required for normal biochemical functions of the human body. Among all five major minerals calcium is essentially required by children, sub-adults and adult male and females. Calcium makes nearly $99 \%$ minerals in bones and teeth, and the other $1 \%$ in extracellular fluids, intracellular structures and cell membranes. ${ }^{1}$ Second element which is essentially required is phosphorus that makes up about $1 \%$ of a person's body weight. ${ }^{2}$ Potassium, sodium, chlorine and magnesium make up only about $0.85 \%$ of the weight of the body. Together eleven chemical elements make up $99.85 \%$ of the body and required as micronutrients., ${ }^{3,4}$ Other minerals include non-organic salts of magnesium, potassium, fluoride and citrate in the trace in trace elements ${ }^{4}$ (Table 1$)$.

Ocean is a largest reservoir of bio-minerals and all its organisms possess mineralized products as composite materials that are comprised of both mineral and organic components. Living organisms get these minerals through the process of biomineralization. Biomeneralization is mainly formation of calcium-containing phosphate, carbonate, oxalate and other mineral types. This process is also related with hardening or stiffness of the mineralized materials (Table 1). It occurs in many phases as different minerals posses different properties such as shape, size, crystallinity, isotopic and trace element compositions quite unlike its inorganically formed counterpart (Figure 1). Among all biominerals calcium-bearing minerals comprise about $50 \%{ }^{5}$ because calcium fulfills many fundamental functions in cellular metabolism. ${ }^{6-8}$ This dominance of calcium-bearing minerals makes widespread common usage as calcification. Granules of amorphous hydrous iron phosphate deposited as granules in the skin of the holothurian, Molpadia are alternate of calcium minerals that is available in nature. ${ }^{9}$ The calcium carbonate minerals are the most abundant biogenic minerals, both in terms of the quantities produced and their widespread distribution among many different taxa. ${ }^{5}$ Of the eight known polymorphs of calcium carbonate, seven are crystalline and one is amorphous. Three of the polymorphs-calcite, aragonite and vaterite-are pure calcium carbonate, while two-monohydrocalcite and the stable forms of amorphous calcium carbonate-contain one water molecule per calcium carbonate. ${ }^{10}$

Calcium is major structural element in vertebrate skeleton (bones and teeth) in the form of calcium phosphate $\left(\mathrm{Ca}_{10}\left(\mathrm{PO}_{4}\right)_{6}(\mathrm{OH})_{2}\right.$ known as hydroxyapatite (Figure 2). It is key component in the maintenance of the cell structure. It also has important role in bone remodeling and tooth re-mineralization is well known. However, calcium also plays a very imperative role in many biochemical reactions, which are essential for normal functioning of cells. Membrane rigidity, permeability and viscosity are partly dependent on local calcium concentration. The most abundantly produced phosphate mineral is carbonated hydroxyapatite, also called dahllite. ${ }^{5}$ It is mainly found in vertebrate bones and teeth, as well as in the shells of inarticulate brachiopods. Biogenic carbonate apatite crystals are usually plate- 
shaped and are exceedingly small i.e. $2-4 \mathrm{~nm}$ thick and some tens of nanometers long and wide ${ }^{11}$ (Table 1). Over 99 percent of total body calcium is found as calcium hydroxyapatite $\left(\left(\mathrm{Ca}_{10}\left(\mathrm{PO}_{4}\right)_{6}(\mathrm{OH})_{2}\right.\right.$ in bone and teeth, where it provides hard tissue with its strength. At any time most of the calcium in the body exists as the mineral hydroxyapatite. In plasma $45 \%$ of calcium is found in ionized form or physiologically active form, $45 \%$ bound to proteins that occur predominantly in albumin. $10 \%$ is complexed with anions such as citrate, sulfate and phosphate. It is the most suitable ceramic material for hard tissue replacement implant from the point of view of biocompatibility. It has the chemical similarity with the mineral portions of hard tissue (e.g. calcium+phosphorous).

Table I Showing major role of important bio-minerals in regeneration and tissue engineering

\begin{tabular}{|c|c|c|c|c|}
\hline Bio-mineral & Form & Origin & Biomedical use & $\begin{array}{l}\text { Safety } \\
\text { standard }\end{array}$ \\
\hline $\begin{array}{l}\text { Calcium phosphate } \\
(\mathrm{CaP})\end{array}$ & $\begin{array}{l}\text { Calcium Phosphate } \\
\text { hydroxylapatite,dahllite, } \\
\text { octa-calcium phosphate }\end{array}$ & $\begin{array}{l}\text { Endoskeleton, ion store, pathological } \\
\text { mineralizations and those that are used } \\
\text { for the repair of mineralized tissues. } \\
\text { Scaffolds, triggering cell differentiation, } \\
\text { bone formation, }\end{array}$ & $\begin{array}{l}\text { Calcium phosphate biomaterials } \\
\text { are successfully used in cranio- } \\
\text { maxillofacial, dental, and orthopedic } \\
\text { surgery. }\end{array}$ & High \\
\hline $\begin{array}{l}\mathrm{CaC}_{2} \mathrm{O}_{4} \cdot 2 \mathrm{H}_{2} \mathrm{O} \\
\text { (weddellite) or } \\
\text { as } \mathrm{CaC}_{2} \mathrm{O}_{4} \cdot 2 \mathrm{H}_{2} \mathrm{O} \\
\text { (whewellite). }\end{array}$ & $\begin{array}{l}\text { Tetragonal crystallites, } \\
\text { whewellite are acute } \\
\text { points and general star- } \\
\text { like shape }\end{array}$ & Cactaceae species & $\begin{array}{l}\text { and a definite calcium oxalate } \\
\text { biomineral seems to be a useful } \\
\text { tool for plant identification and } \\
\text { chemotaxonomy }\end{array}$ & Low \\
\hline Autunite & $\begin{array}{l}\mathrm{UO}_{22}+\text { minerals such as } \\
\left(\mathrm{Ca}\left(\mathrm{UO}_{2}\right) 2\left(\mathrm{PO}_{4}\right) 2 \cdot 10 \text { - }\right. \\
\left.\mathrm{I}_{2} \mathrm{H}_{2} \mathrm{O}\right) \text { or } \\
\text { polycrystalline } \\
\mathrm{HUO}_{2} \mathrm{PO}_{4}\end{array}$ & $\begin{array}{l}\text { Autunite is a radioactive orthorhombic } \\
\text { mineral which results from the } \\
\text { hydrothermal alteration of uranium } \\
\text { mineral }\end{array}$ & $\begin{array}{l}\text { may form thus reducing the mobility } \\
\text { of UO } 22+\text {. Compared to the direct } \\
\text { addition of inorganic phosphate to } \\
\text { contaminated groundwater }\end{array}$ & Low \\
\hline $\begin{array}{l}\text { Monohydrocalcite } \\
\text { calcium carbonate } \\
\text { minerals }\end{array}$ & $\mathrm{CaCO} \cdot \mathrm{HO}$ & $\begin{array}{l}\text { Echinoderms and coelenterates, } \\
\text { granules in the skin of the holothurian, } \\
\text { Molpadia }\end{array}$ & $\begin{array}{l}\text { biogenic minerals, both in terms of } \\
\text { the quantities produced }\end{array}$ & Medium \\
\hline $\begin{array}{l}\text { Amorphous } \\
\text { hydrous iron } \\
\text { phosphate }\end{array}$ & $3 \mathrm{Fe}_{2} \mathrm{O}_{3} \cdot 2 \mathrm{P}_{2} \mathrm{O}_{5} \cdot 10 \mathrm{H}_{2} \mathrm{O}$ & Dermal granules of Molpadia intermedia & facilitates rapid ion diffusion & Medium \\
\hline $\begin{array}{l}\text { Hydroxyapatite a } \\
\text { natural mineral }\end{array}$ & $\mathrm{Ca}_{10}\left(\mathrm{PO}_{4}\right)_{6}(\mathrm{OH})_{2}$ & Osteoid matrix & $\begin{array}{l}\text { crystalline complex of calcium and } \\
\text { phosphate }\end{array}$ & High \\
\hline $\begin{array}{l}\text { Superparamagnetic } \\
\text { iron oxide } \\
\text { nanoparticles }\end{array}$ & SPIONs & $\begin{array}{l}\text { (SPIONs) are also used in bone } \\
\text { regeneration }\end{array}$ & $\begin{array}{l}\text { superparamagnetic iron oxide } \\
\text { nanoparticles (SPIONs), used in drug } \\
\text { delivery application, }\end{array}$ & $\begin{array}{l}\text { Biocompatible } \\
\text { High }\end{array}$ \\
\hline $\begin{array}{l}\text { Calcium oxides, } \\
\text { hydroxides, and } \\
\text { sulfides }\end{array}$ & $\begin{array}{l}\mathrm{CaO} \text { and is a white } \\
\text { crystalline substance. } \\
\mathrm{Ca}(\mathrm{OH})_{2}\end{array}$ & $\begin{array}{l}\text { Because calcium oxide does not occur } \\
\text { naturally, its production is generally from } \\
\text { calcium carbonate or limestone. }\end{array}$ & $\begin{array}{l}\text { quicklime is in the basic oxygen } \\
\text { steelmaking }\end{array}$ & $\begin{array}{l}\text { Hazardous } \\
\text { causes } \\
\text { coughing, } \\
\text { sneezing, } \\
\text { labored } \\
\text { breathing. }\end{array}$ \\
\hline $\begin{array}{l}\text { Calcium silicate } \\
\text { (CS) - }\end{array}$ & $\mathrm{Ca}_{2} \mathrm{SiO}_{4}$ & $\begin{array}{l}\text { Calcium silicate, also known as slag, is } \\
\text { produced when molten iron is made } \\
\text { from iron ore }\end{array}$ & $\begin{array}{l}\text { based materials play an important } \\
\text { role in the development of } \\
\text { endodontic materials that induce } \\
\text { bone/cementum tissue regeneration } \\
\text { and inhibit bacterial viability }\end{array}$ & $\begin{array}{l}\text { sealant } \\
\text { to cured } \\
\text { concrete or } \\
\text { the shells of } \\
\text { fresh eggs }\end{array}$ \\
\hline Calcium carbonate & $\begin{array}{l}\text { Calcite or aragonite } \\
\text { Or Vaterite }\end{array}$ & $\begin{array}{l}\text { Foraminifera Coccolithophores, corals, } \\
\text { Many marine organisms, plants Shell, } \\
\text { test, eye lens,crab cutide,eggshells, }\end{array}$ & $\begin{array}{l}\text { exoskeleton,optical mechanical } \\
\text { strength, protection, gravity } \\
\text { receptors, Ca store }\end{array}$ & Low \\
\hline
\end{tabular}


Table Continued.

\begin{tabular}{|c|c|c|c|c|}
\hline Bio-mineral & Form & Origin & Biomedical use & $\begin{array}{l}\text { Safety } \\
\text { standard }\end{array}$ \\
\hline $\begin{array}{l}\text { Apatite (phosphate } \\
\text { carbonate }\end{array}$ & & Vertebrate teeth (enamel) bone, & & Low \\
\hline Mg-Calcite & $(\mathrm{MgxCalx}) \mathrm{CO}_{3}$ & Foraminiferal calcite & calcification processe & Low \\
\hline $\begin{array}{l}\text { Monohydrate } \\
\text { calcite }\end{array}$ & $\mathrm{CaCO}_{3} \cdot \mathrm{H}_{2} \mathrm{O}$ & $\begin{array}{l}\text { Calcareous tufa, travertine, stalactite and } \\
\text { stalagmite. }\end{array}$ & $\begin{array}{l}\text { Paints, Inks, Powder Coating and } \\
\text { Ceramic Industry }\end{array}$ & Low \\
\hline Protodolomite & $\mathrm{CaMg}\left(\mathrm{CO}_{3}\right)_{2}$ & $\begin{array}{l}\text { Metastable single-phase rhombohedral } \\
\text { carbonates }\end{array}$ & & \\
\hline $\begin{array}{l}\text { Octacalcium } \\
\text { phosphate }\end{array}$ & $\mathrm{Ca}_{8} \mathrm{H}_{2}\left(\mathrm{PO}_{4}\right)_{6}$ & $\begin{array}{l}\text { CP-based materials could be good } \\
\text { candidates for an advanced material } \\
\text { compatible to autologous bone }\end{array}$ & Implanted in various bone defects & \\
\hline Brushite & $\mathrm{CaHPO}_{4} \cdot \mathrm{H}_{2} \mathrm{O}$ & $\begin{array}{l}\text { Occasionally found in dental calculus } \\
\text { and renal calculi. }\end{array}$ & Brushite kidney stones & Harmful \\
\hline Francolite & $\mathrm{Ca}_{10}\left(\mathrm{PO}_{4}\right) 6 \mathrm{~F}_{2}$ & Earthy, pulverulent, foliated & & \\
\hline $\begin{array}{l}\text { Carbonated- } \\
\text { hydroxyapatite }\end{array}$ & $\mathrm{Ca}_{5}\left(\mathrm{PO}_{4} \cdot \mathrm{CO}_{3}\right) 3(\mathrm{OH})$ & $\begin{array}{l}\text { Synthesized starting from calcium } \\
\text { nitrate tetrahydrate, diammonium } \\
\text { hydrogen phosphate and sodium } \\
\text { hydrogen carbonate }\end{array}$ & $\begin{array}{l}\text { Good biocompatibility and } \\
\text { osteointegration of the CHA implant, } \\
\text { osteoconductive properties and } \\
\text { earlier bioresorption }\end{array}$ & \\
\hline $\begin{array}{l}\text { Graphene-based } \\
\text { nanomaterials }\end{array}$ & $\begin{array}{l}\text { nHA/GLY-CHI } \\
\text { composites }\end{array}$ & $\begin{array}{l}\text { Nanocomplexes for innovative } \\
\text { therapeutic strategies and } \\
\text { biodiagnostics. }\end{array}$ & $\begin{array}{l}\text { osteoinductive for human bone } \\
\text { marrow mesenchymal stem cells }\end{array}$ & High \\
\hline
\end{tabular}

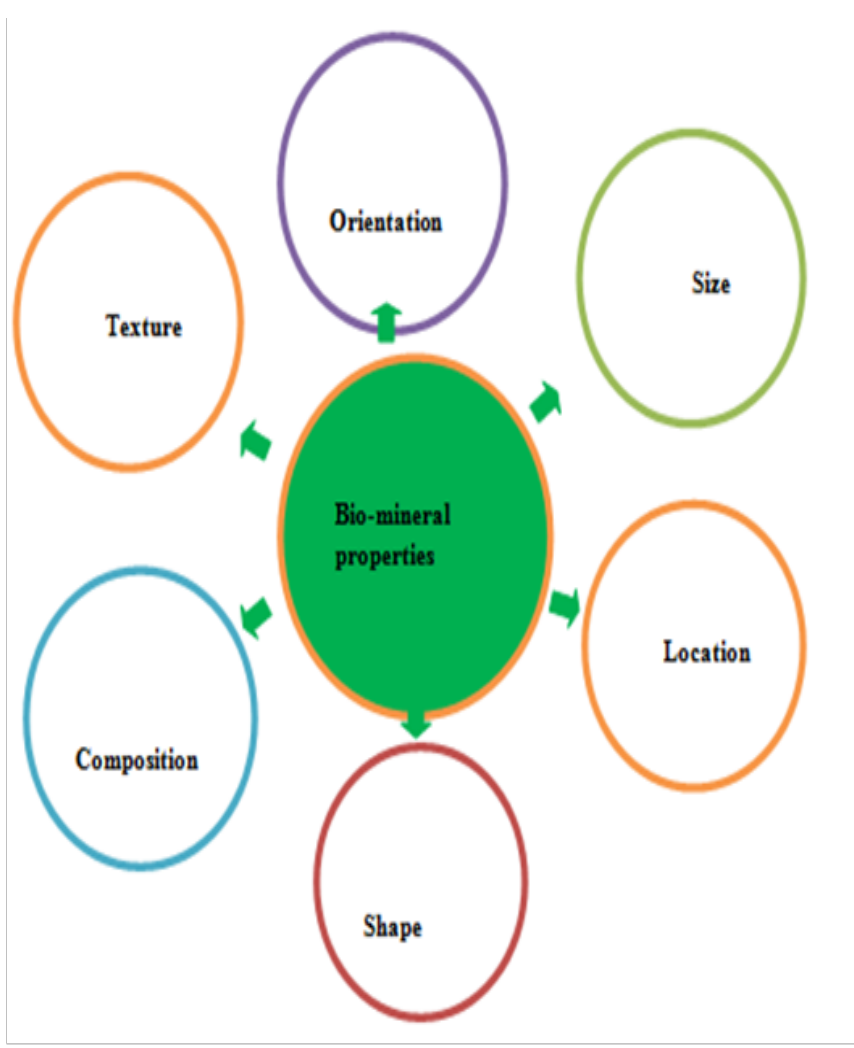

Figure I Showing basic properties of bio-minerals.

Hydroxylapatite, also called hydroxyapatite (HA), is a naturally occurring mineral form of calcium apatite with the formula $\mathrm{Ca}_{5}\left(\mathrm{PO}_{4}\right)_{3}(\mathrm{OH})$, but is usually written $\mathrm{Ca}_{10}\left(\mathrm{PO}_{4}\right)_{6}(\mathrm{OH})_{2}$ to denote that the crystal unit cell comprises two entities. Hydroxylapatite is the hydroxyl endmember of the complex apatite group. Here, the $\mathrm{OH}^{-}$ions can be replaced by fluoride, chloride or carbonate, producing flourapatite or chlorapatite. It crystallizes in the hexagonal crystal system. Calcium and phosphorus are used to form apatite layer. Pure hydroxylapatite powder is white. Naturally occurring apatites can, however, also have brown, yellow, or green colorations, comparable to the discolorations of dental fluorosis. The iron biominerals are not included in mineral class because they have significant occurrences as oxides, hydroxides, and sulfides. ${ }^{12,13}$ Some iron sulfate and phosphate minerals are also reported..$^{14} \mathrm{~A}$ second characteristic of biominerals is that many are actually composites or agglomerations of crystals separated by organic material (Table 1). Microcrystalline hydroxyapatite (MCHC) is an excellent form of calcium for building bone. MSHC is mostly calcium and phosphorous. This unique extract contains the bone crystal calcium hydroxyapatite (Figure 5). MSHC also contains about 40 different minerals, amino acids and growth factors in similar proportions to those found in bones.

As bio-minerals are essential constituents of ECS, and skeleton, these are also required for repairing and wound healing of body organs. Hovered, remineralization of grafted tissues, bones and cartilages is highly important for pre and post tissue repairing. It assists the grafts to attain biocompatibility and cellular adhesion. Remineralization of dentin during dental caries is of great clinical interest in which few proteins have their direct role. Dentin matrix protein 1 (DMP1) is a non-collagenous calcium-binding protein that plays a critical role in biomineralization. ${ }^{15}$ Similarly, amelogenin, the major protein of forming dental enamel, plays a crucial role in the biomineralization. ${ }^{16}$ It supports intrinsic structural flexibility to accommodate interactions in enamel biomineralization. Transforming growth factor beta receptor II interacting protein 1 (TRIP-1) is an intracellular protein that participates in matrix mineralization. ${ }^{17}$ It is localized in the ECM of bone. 


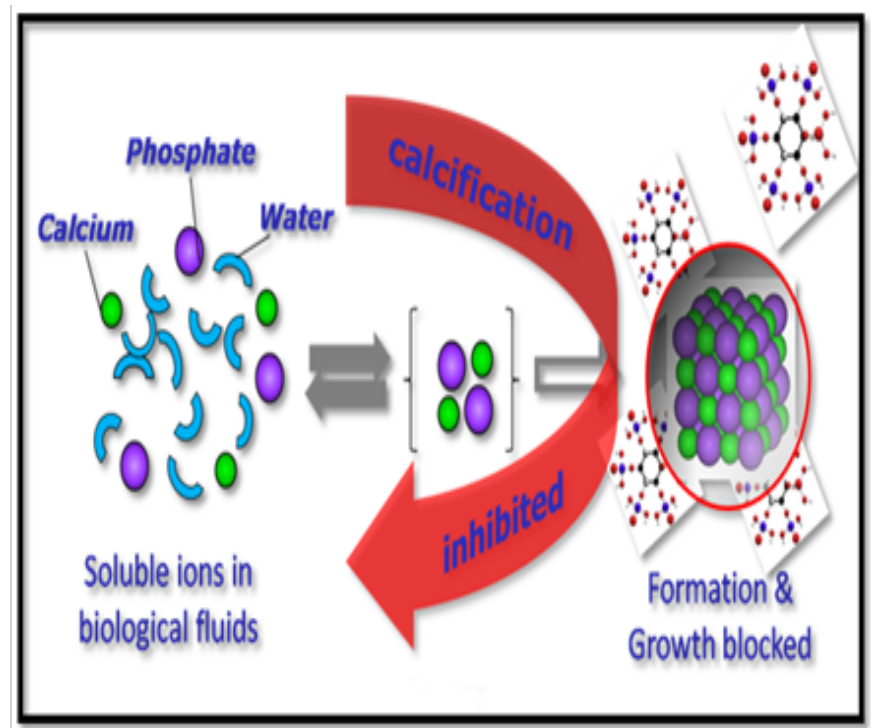

Figure 2 Showing action of calcium, phosphate and water in calcification mechanism.

\section{Properties of bone tissue}

Bone is a dynamic, hard dense connective tissue. It contains a honey comb like matrix internally, which helps to form bone rigidity and acts as a mineral reservoir. Bone is a mineralized tissue composed of a natural organic matrix strengthened by deposits of calcium phosphate crystals. It is structurally composed of extracelleular matrix and cells. The ECM includes minerals, organic materials and water. The mineral part of the bone matrix is mainly composed of calcium and phosphate in the form of hydroxypatite crystals. Human bone is a modified form of hydroxylapatite ${ }^{18}$ that is a natural mineral structure which forms crystal lattice of bones and teeth. It is commonly used as a filler to replace amputated bone or as a coating to promote bone in growth into prosthetic implants. ${ }^{19}$ More exceptionally, modified hydroxylapatite is used for the preparation of artificial bone substances for implants and a large variety of drugs for curing different lesions of bone, soft and mucous tissues of the individual. Microcrystalline hydroxylapatite $(\mathrm{MH})$ is marketed as a bone-building supplement with superior absorption in comparison to calcium..$^{20}$ It is a second-generation calcium supplement derived from bovine bone. ${ }^{20}$ Dentin is a calcified tissue of the body and, along with enamel, cementum and pulp is one of the four major components of teeth. Dentin is a bone-like matrix that is porous and yellow-hued material. It is made up of $70 \%$ inorganic materials mainly carbonated calcium-deficient hydroxylapatite mineral and some non-crystalline amorphous calcium phosphate. Calcified bone contains about $25 \%$ organic matrix (2-5\% of which are cells), $5 \%$ water and $70 \%$ inorganic mineral (hydroxyapatite) (Figure 3). It contains 20-25\% organic materials; $90 \%$ of which is collagen type 1 and the remaining $10 \%$ ground substance that includes dentine-specific proteins. It also contains $10 \%$ water which is absorbed on the surface of the minerals or between the crystals. By weight, $45 \%$ of dentin consists of the mineral hydroxylapatite, $33 \%$ is organic material, and $22 \%$ is water The hardness and rigidity of bone is due to the presence of mineral salt in the osteoid matrix, which is a crystalline complex of calcium and phosphate (hydroxyapatite) (Table 1). Endocrine systems regulate the level of calcium and phosphate ions in the circulating body fluids. Calcium phosphate is used as biomaterial in repair of bone, regeneration of dentin and remineralization of enamel (Figure 3).

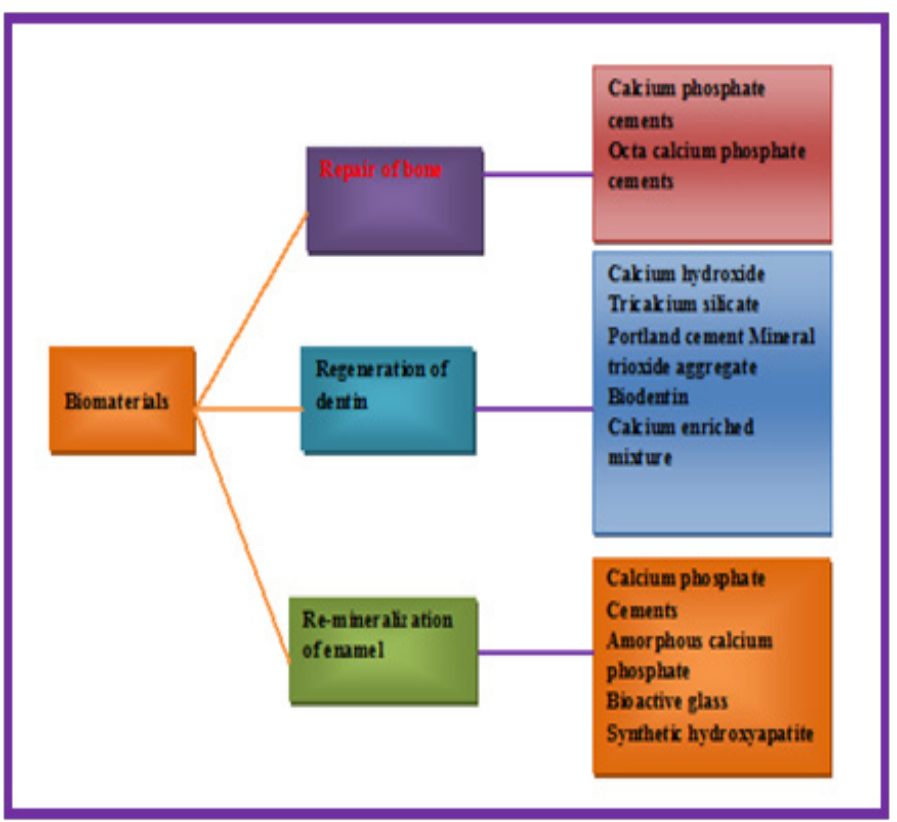

Figure 3 Showing use of calcium phosphate as biomaterial in repair of bone, regeneration of dentin and remineralization of enamel.

Bone tissue is a mineralized tissue of two types, cortical and cancellous bone. Other types of tissue found in bones include bone marrow, endosteum, periosteum nerves, nerves, blood vessels and cartilage (Table 1). Bone tissue contains mineralised matrix made up of an organic component collagen called ossein and an inorganic component of bone mineral made up of various salts. The organic matrix is composed of collagen type I fibers (approximately 95\%) and of proteoglycans and numerous non-collagenous proteins $(5 \%)$. This organic matrix, calcified by calcium phosphate minerals, embeds bone cells, which participate in the maintenance and organization of bone, namely osteoprogenitor cells, osteoblasts, osteocytes, and osteoclasts. Osteoblasts and osteocytes are involved in the formation and mineralization of bone; osteoclasts are involved in the resorption of bone tissue. Modified (flattened) osteoblasts become the lining cells that form a protective layer on the bone surface. Osteoblasts are involved in the creation and mineralization of bone tissue. Osteoblasts are mononucleate bone-forming cells found on the surface of osteon and make a protein mixture known as osteoid, which mineralizes to become bone. ${ }^{21}$ Osteoid is primarily composed of Type I collagen. Osteoblasts and osteocytes are derived from osteoprogenitor cells, but osteoclasts are derived from the same cells that differentiate to form macrophage and monocytes. ${ }^{21}$ Within the marrow of the bone hematopoietic stem cells also reside which give rise to other cells, including white blood cells, red blood cells, and platelets. ${ }^{21}$ Osteoblasts also manufacture hormones, such as prostaglandins, to act on the bone itself.

Bone matrix is slightly monochromate inducting the presence of glycosaminoglycans (CAG) which includes chondriatin sulfate and keratin sulfate. It is mucopolysaccharides with long unbranched polysaccharides consisting of a repeating disaccharide unit. The repeating unit (except for keratan) consists of an amino sugar ( $\mathrm{N}$-acetylglucosamine or $\mathrm{N}$-acetylgalactosamine) along with uronic sugar (glucuronic acid or iduronic acid) or galactose. GAGs are responsible for bones comprehensive resistance. These macromolecules play a role in matrix mineralization. Cartilage 
matrix includes collagen, proeoglycan and non-collgenous proteins. Collagen constituents two third of cartilage dry weight in an adult and it forms interwoven stroma responsible for the tissues tensile strength. Throughout life process of physiological removal, and replacement of bone occurs continuously, without affecting the shape or density of the bone through a sequence of events. All it happens after osteoclasts activation, resorption of bone, osteoblasts activation, and formation of new bone at the site of resorption. ${ }^{22}$ Bone is constantly renewed by the balanced action of osteoblastic bone formation and osteoclastic bone resorption. These mainly occur at the bone surface. This restructuring process of bone remodeling is important not only for normal bone mass and strength, but also for mineral homeostasis. ${ }^{23}$

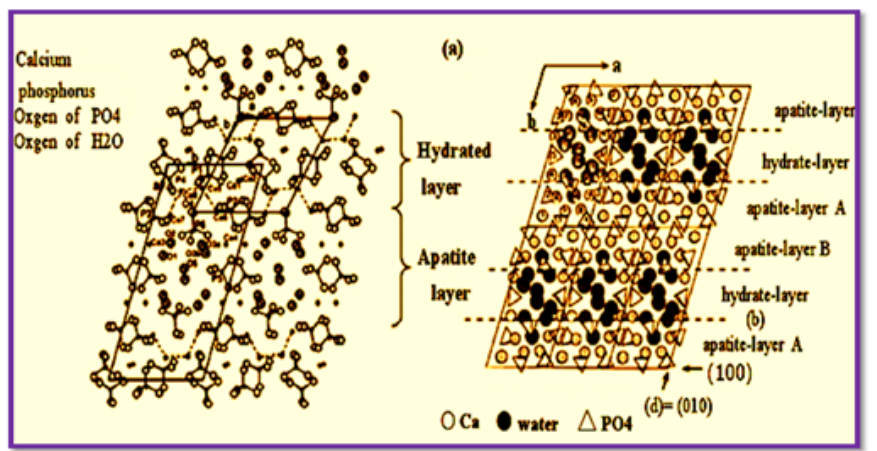

Figure 4 Showing formation of apatite layer by using calcium phosphorus.

\section{Bone engineering}

Natural Polymer-Cell bioconstructs are used for bone tissue engineering. ${ }^{24}$ Bioconstructs substitute the functionality of damaged natural bone structures if critical-sized defects occur. For joining and bound healing of broken bones or for orthopedic and dental applications calcium phosphate bioceramics are widely used. It has a unique characteristic for bone substitution compared with other biomaterials. Porous scaffolds are used for stimulation of bone formation and bone bonding, both related to the specific interactions of their surface with the extracellular fluids and cells, i.e, ionic exchanges, superficial molecular rearrangement and cellular activity. Calcium phosphate scaffolds showed compositional resemblance to bone mineral that they induce a biological response similar to the one generated during bone remodeling. Bone remodeling or renewal is also done for resorption of old bone mineral coupled with the formation of new bone. During resorption the degradation products of calcium phosphate bioceramics such as calcium and phosphate ions are naturally metabolized and they do not induce abnormal calcium or phosphate levels in urine, serum, or organs mainly liver, skin, brain, heart, kidney, lung, and intestine. ${ }^{25}$ Naturally porous calcium phosphates biomaterials was found more relevant scaffold candidates in bone tissue engineering ${ }^{26,27}$ (Table 1). Technically, for having better constructs several procedures have been developed to tailor the scaffolds, such as rapid prototyping, ${ }^{28}$ phase mixing, ${ }^{29}$ use of porogenic agents,${ }^{30}$ or shape replication. ${ }^{31}$ It depends on selecting and/or combining calcium phosphate phases, resorption kinetics and stimulation of bone formation. ${ }^{32-37}$ Calcium phosphate biomaterials are successfully used in cranio-maxillofacial, dental, and orthopedic surgery. They are of synthetic origin (obtained after aqueous precipitation or after sintering) or natural origin (freezedried or banked bone and derived coral hydroxyapatite), and they are used as bone fillers in the form of cement or granules. As they cannot replace as such the load-bearing functions of bone because of their lower mechanical properties, they are also successfully used as coatings on metallic hip and dental implants in clinics. ${ }^{38}$

In regenerative medicine and tissue engineering stem cells with multipotent and self-renewal abilities (HPSc and MSCs) also play a vital role to make bio-artificial constructs in culture media. Stem cells grown in specific micro niche assist to make tissue reconstructs through specific cellular differentiation and secretion of various bioactive macromolecules. For cellular proliferation and differentiation of stem cells special support materials are required. Sintered hydroxyfluorapatite discs are used to support cellular proliferation and colonization. Scaffolds that mimic the structure and composition of bone tissue and cells play important role in bone tissue engineering applications. But these should possess proper composition and biocompatibility both in artificial cultures and in vitro tissue grafting. More specifically, only natural polymer-based scaffolds consisting in proteins, polysaccharides, minerals, growth factors etc, are used because they support and enhance interaction between scaffolds and cells. However, to make more functional bone forming smart biomaterials and transplantable composite grafts desirable tissue bio-constructs are to be generated in vitro. Further, to regenerate bone tissue maintenance angiogenic potential of grafted cells is highly required. The other components which are required to generate three-dimensional tissues like fibrin, thrombin, collagen, hydroxyapatite, and beta-tricalcium phosphate in different compositions and concentrations. Phosphate-based glass is also a potential biomaterial that is used for bone repair because of its degradation properties. It control and allow the release of various elements to promote osteogenic tissue growth ${ }^{39}$ (Table 1). Degradation of zinc containing phosphate-based glass is used as a material for orthopedic tissue engineering mainly to replace lost/degenerated tissues or organs. For wound healing calcium oxide can be replaced with zinc oxide in proportion less than $10 \%$ put a positive effect on bone forming cells.

\section{Role of mineral elements in osteogenic diffe- rentiation}

Osteoprogenitor cells play a significant role in the growth or repair of bones. These are potential cell sources for regenerative medicine and bone tissue engineering but control of their specific differentiation into bone cells is an important issue. BMP-2 grafted nHA/PLGA hybrid nanofiber scaffold stimulates osteoblastic cells growth. ${ }^{40}$ It is also used as a nanodrug carrier for the controlled and targeted delivery of BMP-2 which enhances bone tissue regeneration and used in treatment of various bone-related diseases. ${ }^{40}$ Similarly, electrically conductive scaffold act as the skeleton of stem cell niche in regenerative medicine. ${ }^{41}$ In addition, injectable calcium phosphate/ hyaluronic acid microparticle system is also used for platelet delivery for bone regeneration ${ }^{42}$ (Table 1). Graphene-based nanomaterials are also used as substrates for stem cell (SC) differentiation. ${ }^{43}$ Osteogenic differentiation of human mesenchymal stem cells is stimulated by reduced graphene oxide level. Osteoclast differentiation from human blood precursors can be enhanced by using biomimetic calciumphosphate substrates. ${ }^{44}$ Insulin-transferrin-selenium is also play important role in auricular chondrocyte proliferation and engineered cartilage formation in vitro. ${ }^{45}$ It helps to retain chondrogenic phenotypes, and promoted engineered cartilage formation when combined with FBS, which is potentially used as key supplementation in auricular chondrocytes and engineered cartilage culture. Despite 
the biocompatibility and osteoinductive properties of calcium phosphate $(\mathrm{CaP})$ cements their low biodegradability hampers full bone regeneration.

Similar to $\mathrm{Ca}(2+)$, extracellular $\mathrm{Mg}(2+)$ plays an important role in the functions of the skeletal system. But high extracellular magnesium inhibits mineralized matrix deposition and modulates intracellular calcium signaling in human bone marrow-derived mesenchymal stem cells. ${ }^{46}$ High extracellular $\operatorname{Mg}(2+)$ concentration $([\mathrm{Mg}(2+)]$ e) inhibits extracellular matrix mineralization in hBMSCs in vitro. But a high magnesium environment created by the rapid corrosion of $\mathrm{Mg}$ alloys may result in the dysfunction of calcium-dependent physiology processes and become disadvantageous to hBMSCs physiology. $\mathrm{Ca}(2+)$ signaling also plays an important role in self-renewal and neural differentiation of embryonic stem cells (ESCs) ${ }^{47}$ In this mechanism intracellular $\mathrm{Ca}(2+)$ mobilization is mediated by RyRs (ryanodine receptors); by cADPR (cyclic adenosine 5'-diphosphate ribose) and CD38 (cluster of differentiation 38/cADPR hydrolase); and by NAADP (nicotinic acid adenine dinucleotide phosphate) and TPC2 (two pore channel 2). Similarly, excitation-contraction coupling (ECC) bridge between cardiac electrical activation and mechanical contraction is also driven by the influx of $\mathrm{Ca}(2+)$ across the sarcolemma. Because it triggers $\mathrm{Ca}(2+)$ release from the sarcoplasmic reticulum (SR) - a process termed $\mathrm{Ca}(2+)$-induced $\mathrm{Ca}(2+)$ release (CICR) - followed by re-sequestration of $\mathrm{Ca}(2+)$ into the SR. The sodium calcium exchanger (NCX) inextricably couples the cycling of $\mathrm{Ca}(2+)$ and $\mathrm{Na}(+)$ in cardiac myocytes. However, neuronal sodium channels are important components of the nano-machinery of cardiac calcium cycling. ${ }^{48}$ Similarly, CaM-dependent protein kinase II $\alpha$ $(\mathrm{CaMKII} \alpha)$ acts in calcium signaling mechanism in ischemic injury. ${ }^{49}$ However, to maintain cytosolic calcium concentrations and generate spontaneous calcium oscillations in mesenchymal stem cells electric pulses are used. ${ }^{50}$ For improving and accelerating the differentiation and functional maturation of human stem cell-derived neurons extracellular calcium and GABA play important role. ${ }^{51}$ Monolithic calcium phosphate/poly(lactic acid) composite versus calcium phosphate-coated poly(lactic acid) are also used to support osteogenic differentiation of human mesenchymal stromal cells. ${ }^{52}$

\section{Use of biocomposite nanomaterials}

Biocomposite nanomaterials are used in bone bounds and healing. These are on high demand of various biomaterials at global level. Moreover, nHA/GLY-CHI composites are used in tissue engineering of bone, cartilage and periodontal. These composites are osteoinductive for human bone marrow mesenchymal stem cells (HBMS) and have wider application in tissue engineering ${ }^{53}$ (Table 1). Composite scaffolds of nano-hydroxyapatite and silk fibroin are used to enhance mesenchymal stem cell-based bone regeneration via the interleukin 1 alpha autocrine/paracrine signaling loop. ${ }^{54}$ These scaffolds promote bone regeneration mainly through cell signaling pathway associated with cell-biomaterial interaction. Though, some other soluble factors also play a role in osteoinduction with nHAp-SF. ${ }^{54}$ Superparamagnetic iron oxide nanoparticles (SPIONs) are also used in bone regeneration. These assist in stem cell tracking and noninvasive to cells and tissues. ${ }^{55}$ Similarly, Dex-loaded (dexamethasone-loaded) carboxymethylchitosan/poly(amidoamine) dendrimer nanoparticles are used as intracellular nanocarrier, supplying Dex in a regimented manner and promoting superior ectopic de novo bone formation. ${ }^{56}$ Glycol chitosan/nanohydroxyapatite biocomposites are also used in bone tissue engineering and regenerative medicine.
Naturally occurring porous calcium phosphate is used for making more relevant scaffold candidates in bone tissue engineering ${ }^{26,27}$ (Table 1). But it is also (Calcium phosphates $\mathrm{CaPs}$ ) are among the most utilized synthetic biomaterials for bone regeneration, largely owing to their established osteoconductive and osteoinductive properties.$^{57} \mathrm{CaPs}$ is extensively used synthetic bone graft substitutes, are often combined with other materials. CaPs influence angiogenesis and have wider scope in bone regeneration. Similarly, few cement formulations are also prepared by incorporating HAc microparticles or microparticles loaded with PL (10 and 20wt\%) (Figure 5). Similarly, by using calcium, phosphorus, water porous ACP nanospheres are formed, while HAP nanosheets or nanorods by using microwave assisted hydrothermal method (Figure 6). Similarly, hydroxyapatite (HAp) and alumina scaffolds influence behavior of MC3T3-E1 cells in culture. These cell culture scaffolds are required for the control of cell attachment, proliferation, and differentiation in vitro. ${ }^{58}$ For culturing mouse osteoblast-like MC3T3-E1 cells on novel cell culture scaffolds fabricated using ordered nanometer-sized pores $(100,300,500$, and $1000 \mathrm{~nm}$ ) are most commonly used. Both pore size and constituents of films play a role in controlling the morphology and proliferation rate of MC3T3-E1 cells. ${ }^{58}$ Calcium silicate (CS) -based materials play an important role in the development of endodontic materials that induce bone/cementum tissue regeneration and inhibit bacterial viability $^{59}$ (Table 1). MesoCS nanoparticles are potentially useful endodontic materials for biocompatible and osteogenic dental pulp tissue regenerative materials. Dentin phosphoprotein (DPP) activates integrin-mediated anchorage-dependent signals in undifferentiated mesenchymal cells. ${ }^{60}$

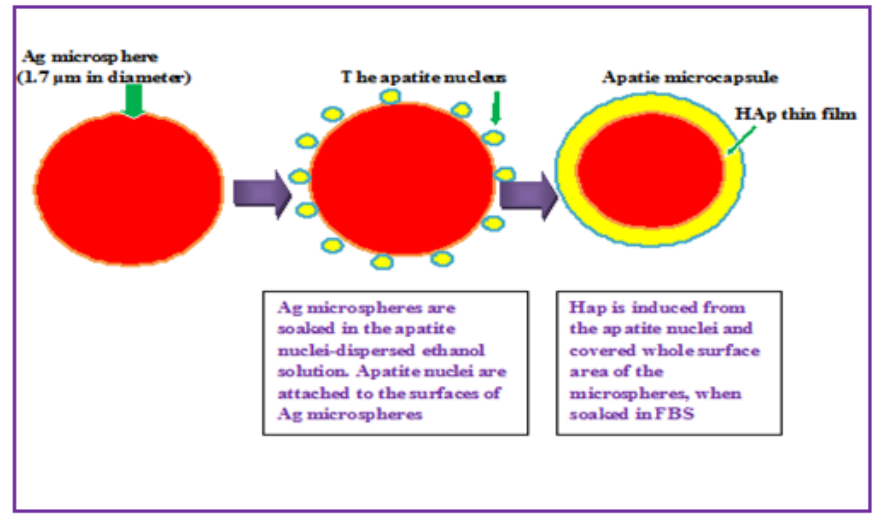

Figure 5 Showing use of $\mathrm{Ag}$ microsphere soaked in appetite for making thin Hap thin film.

Menin, is a product of the MEN1 gene, that is related to the ontogeny of several cancers such as MEN1 and sporadic endocrine tumors. It is a well known tumor suppressor. Menin interacts with many proteins and involve in various biological functions in several tissues. It plays physiological and pathological roles related to transforming growth factor-beta (TGF- $\beta$ ) signaling pathway in the parathyroid. Menin supports BMP-2- and Runx2-induced differentiation of mesenchymal cells into osteoblasts by interacting with Smad1/5, Runx2, $\beta$-catenin and LEF-1, although it has different effects on osteoblasts at later differentiation stages through TGF- $\beta$-Smad3 and AP- 1 pathways. ${ }^{61}$ Silk fibroin (SF) is used in osteoregenerative therapy. It combines and gear extraordinary mechanical properties and directs calciumphosphate formation. The tailoring of the mineralization and mechanical properties of hydrogels through hybridization with FDPs could potentially have a significant impact on cell delivery and bone regenerative medicine. ${ }^{62}$ The electrically conductive scaffold works as 
skeleton of stem cell and to maintain niche in regenerative medicine. Biomimesis is used to enhance the quality and function of regenerated tissues. Biomimetic scaffolds increase extracellular matrix, cellmatrix interaction, and tissue-regenerative signaling. These are also used for craniofacial regeneration ${ }^{63}$ and for replacement of natural body structures of bone tissue as biocompatible grafts. Nacre a microarchitecture is made by using biomimesis that works on a brick-andmortar arrangement. ${ }^{64}$ It is an amazing natural nanocomposite that possesses strong mechanical properties and has wider applications in the field of biomedical, biomematerials science and nanotechnology.

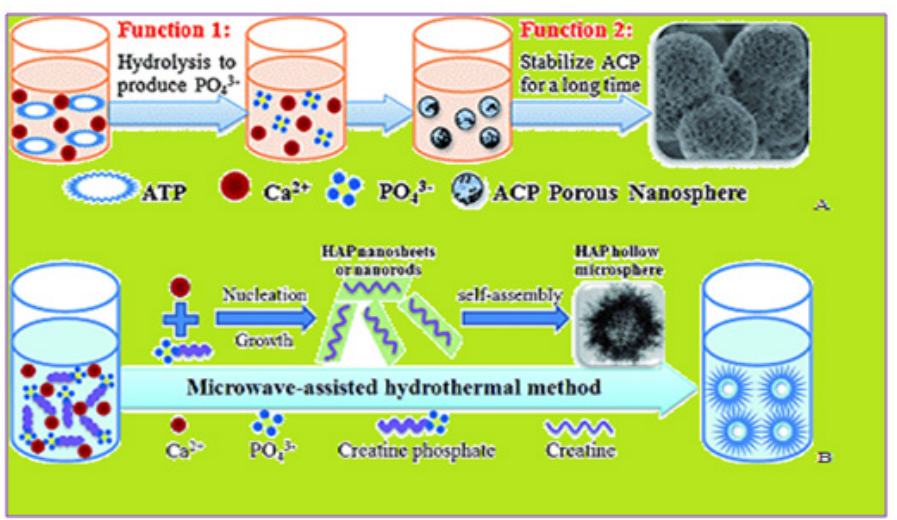

Figure 6 (a) Showing formation of porous ACP nanospheres (b) formation of HAP nanosheets or nanorods by using microwave assisted hydrothermal method.

\section{Calcium homeostasis and tissue regenera- tion}

Calcium as a biomineral has active role in major cellular functions. Its extracellular level is highly important for various physiological activities such as cellular responses and cell signaling. Calcium homeostasis and ligand-dependent calcium signaling are key components of major cellular responses, including cell proliferation, differentiation or apoptosis. ${ }^{65}$ Calcium homeostasis is regulation of the concentration of calcium ions in the extracellular fluid $\left[\mathrm{Ca}^{++}\right]_{\mathrm{ECF}}$. This one of the important mechanism by which the body maintains adequate calcium levels in order to prevent hypercalcemia or hypocalcemia. TRPV1 controls the cellular calcium homeostasis. This parameter is tightly controlled because the calcium ions have a stabilizing effect on voltage-gated ion channels. For instance, when $\left[\mathrm{Ca}^{++}\right]_{\mathrm{ECF}}$ is too low (hypocalcemia), voltage-gated ion channels start opening spontaneously, causing nerve and muscle cells to become hyperactive. The syndrome of involuntary muscle spasms due to low $\left[\mathrm{Ca}^{++}\right]_{\mathrm{ECF}}$ is called hypocalcemic tetany. Conversely, when $\left[\mathrm{Ca}^{++}\right]$ ${ }_{\mathrm{ECF}}$ is too high (hypercalcemia), voltage-gated ion channels don't open as easily, and there is depressed nervous system function. In state of hypercalcemia calcium combines with phosphate ions, forming deposits of calcium phosphate (stones) in blood vessels and in the kidneys. Calcium-sensing receptor regulates cytosolic $[\mathrm{Ca}$ $(2+)$ ] calcium level and plays a major role in the development of pulmonary hypertension. ${ }^{66}$ Cytosolic calcium level in primary human gingival fibroblasts is affected by Cyclosporin A and Angiotensin II. ${ }^{67}$ $\left[\mathrm{Ca}^{++}\right]_{\mathrm{ECF}}$ is influenced by dietary intake, $\mathrm{Ca}^{++}$absorption in the small intestine, and by excretion of $\mathrm{Ca}^{++}$in the urine (Figure 7). Importantly, the bones contain $99 \%$ of the $\mathrm{Ca}^{++}$in the body, so bones provide a reservoir of $\mathrm{Ca}^{++}$that can be used to maintain $\left[\mathrm{Ca}^{++}\right]_{\mathrm{ECF}}$.

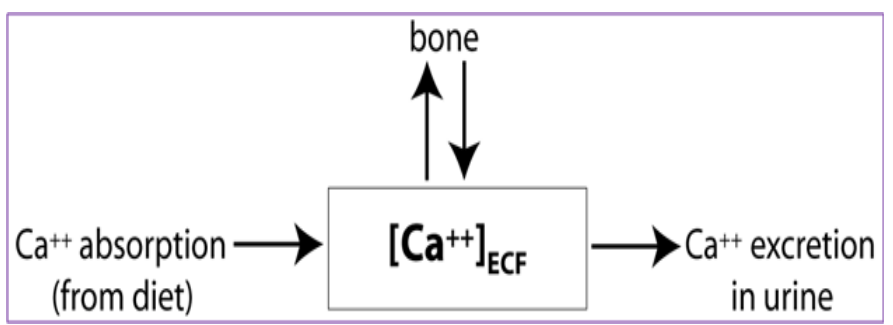

Figure 7 Shows physiological influences on $\left[\mathrm{Ca}^{++}\right]_{\mathrm{ECF}}$

In addition, nutrition factors such as calcium, vitamin D and vitamin K play protective role and assist in integrity of the skeleton. ${ }^{68}$ It is also influenced by certain trace elements e.g. zinc, copper, manganese, magnesium, iron, selenium, boron and fluoride and negatively by others lead, cadmium, cobalt. Deficiency or excess of these elements influence bone mass and bone quality in adulthood as well as in childhood and adolescence. Micronutrients put beneficial effects on bone homeostasis. ${ }^{68}$ Vitamin D is essential for calcium and bone homeostasis. Humans are largely dependent on UVB-radiationinduced photosynthesis of vitamin $\mathrm{D}$, as few foods contain vitamin D. ${ }^{69}$ Parathyroid hormone $(\mathrm{PTH})$ and $1,25(\mathrm{OH})_{2} \mathrm{D}$ (the active form of vitamin D) are important regulators of calcium levels in the body . The major regulator is $\mathrm{PTH}$, which is part of a negative feedback loop to maintain $\left[\mathrm{Ca}^{++}\right]_{\mathrm{ECF}}$ Parathyroid hormone secretion is stimulated by hypocalcemia, and it works through three mechanisms to increase $\mathrm{Ca}^{++}$levels (Figure 8). For maintain systemic $\mathrm{Ca}^{2+}$ homeostasis renal $\mathrm{Ca}^{2+}$ reabsorption is essential. It is tightly regulated through the parathyroid hormone (PTH)/PTHrP receptor (PTH1R) signaling pathway. ${ }^{70}$ In athletes and aerobics exercise-induced decrease in serum ionized calcium (iCa) occurs that trigger an increase in parathyroid hormone $(\mathrm{PTH})$, which stimulate bone resorption. ${ }^{71}$ Hence, an adequate Ca supplementation before and/or during exercise can fully mitigate the exercise-induced decrease in serum $\mathrm{Ca}$ and increases in PTH and bone resorption. ${ }^{71}$

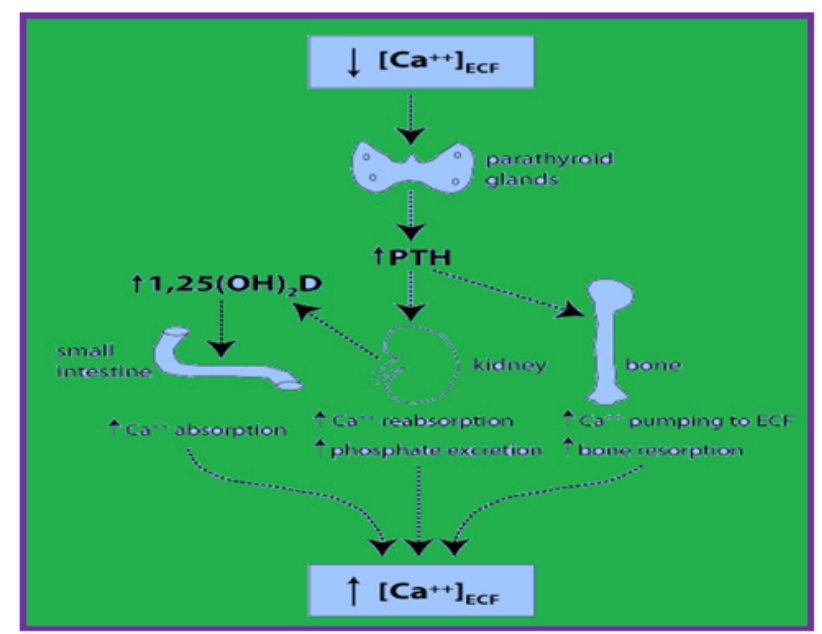

Figure 8 Showing endocrine regulation of $\left[\mathrm{Ca}^{++}\right]$ECF (a) PTH stimulates the release of $\mathrm{Ca}^{++}$from bone, in part by stimulating bone resorption (b) PTH decreases urinary loss of $\mathrm{Ca}^{++}$by stimulating $\mathrm{Ca}^{++}$reabsorption (c) PTH indirectly stimulates $\mathrm{Ca}^{++}$absorption in the small intestine by stimulating synthesis of $1,25(\mathrm{OH})_{2} \mathrm{D}$ in the kidney.

Vitamin D and its' metabolites control whole body calcium homeostasis. These are also part of endocrine system and hormones secreted regulate serum calcium levels but in a very narrow range. ${ }^{72}$ 
Production of the vitamin D endocrine hormone, 1,25 dihydroxyvitamin $\mathrm{D}\left(1,25(\mathrm{OH})_{2} \mathrm{D}\right)$ is regulated by habitual dietary calcium intake and physiologic states like growth, aging, and the menopause. ${ }^{72}$ In bone healing putative effects are generated by cholesterol, hyperlipidemia, and low vitamin D intake. There are some factors which negatively impact osteoclastogenesis or osteal macrophage activation..$^{73}$ The calcium associated tissue homeostasis encompasses activities like proliferation, cell death, cell motility, oxygen, and nutrient supply. ${ }^{74}$ Bone remodeling is stringently regulated by communication between bone component cells such as osteoclasts, osteoblasts and osteocytes. An imbalance of this process is often linked to various bone diseases. ${ }^{75}$

\section{Natural products as bone healers}

Excessive bone resorption is responsible for development of bone erosive diseases, including osteoporosis, rheumatoid arthritis, and periodontitis. Natural products are considered best healers for treatment of bone erosive diseases. These affect the mechanism of osteoclastogenesis and bone resorption. ${ }^{76}$ Bone-resorbing is done by osteoclasts the multinucleated cells, which are differentiated from hemopoietic progenitors of the monocyte/macrophage lineage. The plant origin active ingredients were found efficacious in suppressing osteoclastogenesis and bone resorption. These active compounds are flavonoids, terpenoids (sesquiterpenoids, diterpenoids, triterpenoids), glycosides, lignans, coumarins, alkaloids, polyphenols, limonoids, quinones and others (steroid, oxoxishhone, fatty acid). These natural products exert the inhibitory effects via regulating many factors involved in the process of osteoclast differentiation and bone resorption, including the essential cytokines (RANKL, M-CSF), transcription factors (NFATc1, c-Fos), signaling pathways (NF- $\mathrm{kB}$, MAPKs, Src/PI3K/Akt, the calcium ion signaling), osteoclast-specific genes (TRAP, CTSK, MMP-9, integrin $\beta 3$, OSCAR, DC-STAMP, Atp6v0d2) and local factors (ROS, LPS, NO). In addition, for better healing of contaminated musculoskeletal defect rapidly-resorbing calcium-sulphate pellets containing amikacin are used to reduce the local bacterial count. These locally-administered antibiotics are used to heal wounds in a limb. ${ }^{77}$ Further, to reduce inflammation and immunoreactivity modulation of platelet activation and initial cytokine release by alloplastic bone substitute materials is highly important. ${ }^{78}$

\section{Conclusion}

Biominerals are important for cellular and metabolic activities of our body. These are important natural composite material found in mineralized tissue; the bones. Organic matrix, is calcified by calcium phosphate minerals, embeds bone cells, which participate in the maintenance and organization of bone. Calcium phosphates (CaPs) are among the most utilized biomaterials for bone regeneration. CaPs influence angiogenesis and have wider scope in bone regeneration. These show osteoconductive and osteoinductive properties. Molecular control of tissue regeneration for calcium phosphate $(\mathrm{CaP})$-based materials can be established by defining the parameters critical for tissue induction and those are linked to the molecular circuitry controlling cell physiology. Further, the material properties such as microporosity, ion composition, protein adsorption of a set of synthesized osteoinductive and noninductive $\mathrm{CaP}$ ceramics need to be are parameterized and these properties are correlated to a transcriptomics profile of osteogenic cells grown on the materials in vitro. Biomaterial composition and material engineering are important aspects of bone void filling. Advanced space filling methods and strategies are to be explored to make interface between biomaterials and tissue regeneration. Further, new engineering, designs, composites and methods be required for allowing biomaterials to serve as active orchestrators of the molecular and cellular events of tissue regeneration. It will need linking the transcriptional linking landscape of bone induction to biomaterial design parameters.

For biomaterial-induced bone formation certain active ingredients derived from natural plants were found efficacious because they suppress osteoclastogenesis and bone resorption. Calcium homeostasis and ligand-dependent calcium signaling are key components of major cellular responses, including cell proliferation, differentiation or apoptosis. New scaffolds used in tissue engineering, and components of implant devices must biocompatible, transferable and show implantable properties. All biomaterials if mineralized should opt to show high biocompatibility, low immunoreactivity and inflammatory activity. Further, fluoride substitution of HAP will be a better strategy for the development of certain engineered tissue replacements and tissue regeneration systems using ES cells. There is a need to explore more promising biomaterials which can induce necrosis, inflammation and repair, and operate modulation of platelet activation and initial cytokine release and adsorption. For better repair and wound healing composite design, composition, texture and biocompatibility are important features to be considered. For making age specific grafts and tissue implants mathematical modeling should use to reach a parametric fitness and suitability of biomaterial used. Such integrative approaches will prove much advantageous biological process of bone regeneration inside $\mathrm{CaP}$ scaffolds.

\section{Acknowledgements}

None.

\section{Conflict of interest}

The author declares no conflict of interest.

\section{References}

1. Berdanier Carolyn D, Dwyer Johanna T, Heber David. Handbook of nutrition and food. 3rd ed. USA: CRC Press; 2013. 1136 p.

2. Minerals Medline Plus. USA: National Library of Medicine, US National Institutes of Health; 2016.

3. Micronutrient Information Center. Minerals. USA: Linus Pauling Institute, Oregon State University; 2016.

4. Vitamin and mineral supplement fact sheets. Office of Dietary Supplements. USA: US National Institutes of Health, Bethesda; 2016.

5. Lowenstam HA, Weiner S. On Biomineralization. USA: Oxford University Press; 1989. 336 p.

6. Lowenstam HA, Margulis L. Calcium regulation and the appearance of calcareous skeletons in the fossil record. In: Omori M, Watabe N, editors. 3rd ed. The Mechanisms of Biomineralization in Animals and Plants. Japan: Tokai University Press; 1980. 310 p.

7. Simkiss K, Wilbur K. Biomineralization: Cell Biology and Mineral Deposition. USA: Academic Press Inc; 1989. 337 p.

8. Berridge MJ, Bootman MD, Lipp P. Calcium-A life and death signal. Nature. 1998;395(6703):645-648.

9. Lowenstam HA, Rossman GR. Amorphous, hydrous, ferric phosphatic dermal granules in Molpadia (Holothurodidea): Physical and chemical characterization and ecologic implications of the bioinorganic fraction. Chem Geology. 1975;15(1):15-51. 
10. Addadi L, Raz S, Weiner S. Taking advantage of disorder: amorphous calcium carbonate and its roles in biomineralization. Adv Mat. 2003;15(12):959-970.

11. Weiner S, PRICE PA. Disaggregation of bone into crystals. Calcif Tissue Int. 1986;39(5):365- 375.

12. Bazylinski DA, Moskowitz BM. Microbial biomineralization of magnetic iron minerals: Microbiology, magnetism and environmental significance. Reviews in Mineralogy. 1997;35(1):217-223.

13. Konhauser KO. Bacterial iron biomineralisation in nature. FEMS Microbiol Reviews. 1997;20(3-4):315-326.

14. Konhauser KO. Diversity of bacterial iron mineralization. Earth-Science Rev. 1998;43:91-121.

15. Padovano JD, Ravindran S, Snee PT, et al. DMP1-derived peptides promote remineralization of human dentin. J Dent Res. 2015;94(4):608614.

16. Beniash E, Simmer JP, Margolis HC. Structural changes in amelogenin upon self-assembly and mineral interactions. $J$ Dent Res. 2012;91(10):967-72.

17. Ramachandran A, Ravindran S, Huang CC, et al. TGF beta receptor II interacting protein-1, an intracellular protein has an extracellular role as a modulator of matrix mineralization. Sci Rep. 2016;6:37885.

18. Junqueira Luiz Carlos, José Carneiro. Basic Histology. In: Foltin Janet, Lebowitz Harriet, editors. Text \& Atlas. 10th ed. USA: McGraw-Hill Companies; 2003. 144 p.

19. Straub DA. Calcium Supplementation in Clinical Practice: A Review of Forms, Doses, and Indications. NCP-Nutr Clin Prac. 2007;22(3):286296.

20. Sadat-Shojai Mehdi. Hydroxyapatite: Inorganic Nanoparticles of Bone (Properties, Applications, and Preparation Methodologies) (PDF). Iranian Students Book Agency (ISBA); 2010.

21. Deakin, Barbara Young. Wheater's functional histology: a text and colour atlas. 5th ed. Churchill Livingstone/Elsevier; 2006.

22. Buckwalter JA, Glimcher MJ, Cooper RR, et al. Bone biology. II: Formation, form, modeling, remodeling, and regulation of cell function. Instr Course Lect. 1996;45:387-99.

23. Schmitz JP, Hollinger JO. The critical size defect as an experimental model for craniomandibulofacial non unions. Clin Orthop Relat Res. 1986;205:299-308

24. Titorencu I, Albu MG, Nemecz M, et al. Natural Polymer-Cell Bioconstructs for Bone Tissue Engineering. Curr Stem Cell Res Ther 2017;12(2):165-174.

25. den Hollander W, Patka P, Klein CP, et al. Macroporous calcium phosphate ceramics for bone substitution: a tracer study on biodegradation with 45Ca tracer. Biomaterials. 1991;12(6):569-73.

26. Kruyt MC, Dhert WJ, Yuan H, et al. Bone tissue engineering in a critical size defect compared to ectopic implantations in the goat. J Orthop Res. 2004;22(3):544-51

27. Arinzeh TL, Tran T, McAlary J, et al. A comparative study of biphasic calcium phosphate ceramics for human mesenchymal stem-cell-induced bone formation. Biomaterials. 2005;26(17):3631-8.

28. Wilson CE, de Bruijn JD, Van Blitterswijk CA, et al. Design and fabrication of standardized hydroxyapatite scaffolds with a defined macroarchitecture by rapid prototyping for bone-tissue-engineering research. J Biomed Mater Res A. 2004;68(1):123-32.

29. Li SH, De Wijn JR, Layrolle P, et al. Synthesis of macroporous hydroxyapatite scaffolds for bone tissue engineering. J Biomed Mater Res. 2002;61(1):109-20.
30. Barralet JE, Grover L, Gaunt T, et al. Preparation of macroporous calcium phosphate cement tissue engineering scaffold. Biomaterials. 2002;23(15):3063-72.

31. Tancred DC, McCormack BA, Carr AJ. A synthetic bone implant macroscopically identical to cancellous bone. Biomaterials. 1998;19(24):2303-11.

32. Dhert WJ, Klein CP, Jansen JA, et al. Histological and histomorphometrical investigation of fluorapatite magnesium whit-lockite, and hydroxylapatite plasma-sprayed coatings in goats. $J$ Biomed Mater Res. 1993;27(1):127-38.

33. Dhert WJ, Klein CP, Wolke JG, et al. A mechanical investigation of fluorapatite, magnesium whitlockite, and hydroxylapatite plasmasprayed coatings in goats. J Biomed Mater Res. 1991;25(10):1183-200.

34. Barrere F, Van der Valk CM, Dalmeijer RAJ, et al. Osteogenecity of octacalcium phosphate coatings applied on porous metal implants. $J$ Biomed Mater Res A. 2003;66(4):779-88.

35. Rahbek O, Overgraad S, Soballe K. Fifteen years of clinical experience with hydroxyapatite coatings in joint arthroplasty. In: Epinette J A, Manley MT, editors. Calcium phosphate coatings for implant fixation. Paris: Springer; 2004. p. 35-51.

36. Habibovic P, Yuan H, Van de Doel M, et al. Relevance of osteoinductive biomaterials in a critical-sized defect (accepted). J Orthop Res. 2005;24(5):867-76.

37. Schopper C, Ziya-Ghazvini F, Goriwoda W, et al. HA/TCP compounding of a porous $\mathrm{CaP}$ biomaterial improves bone formation and scaffold degradation - a long-term histological study. J Biomed Mater Res B Appl Biomater. 2005;74(1):458-67.

38. Epinette, Jean Alain. Fifteen years of clinical experience with hydroxyapatite coatings in joint arthroplasty. In: Manley Michael T, editor. Paris: Springer; 2004. 452 p.

39. Qaysi MA, Petrie A, Shah R, et al. Degradation of zinc containing phosphate-based glass as a material for orthopedic tissue engineering. $J M a$ ter Sci Mater Med. 2016;27(10):157.

40. Haider A, Kim S, Huh MW, et al. BMP-2 Grafted nHA/PLGA Hybrid Nanofiber Scaffold Stimulates Osteoblastic Cells Growth. Biomed Res Int. 2015;2015:281909.

41. Babo PS, Cai X, Plachokova AS, et al. The role of a platelet lysatebased compartmentalized system as a carrier of cells and platelet-origin cytokines for periodontal tissue regeneration. Tissue Eng Part A. 2016;22(19-20):1164-1175.

42. Jin L, Lee JH, Jin OS, et al. Stimulated osteogenic differentiation of human mesenchymal stem Cells by reduced graphene oxide. $J$ Nanosci Nanotechnol. 2015;15(10):7966-7970.

43. Jin G, Li K. The electrically conductive scaffold as the skeleton of stem cell niche in regenerative medicine. Mater Sci Eng C Mater Biol Appl. 2014;45:671-81.

44. Ciapetti G, Pompo DG, Avnet S, et al. Osteoclast differentiation from human blood precursors on biomimetic calcium-phosphate substrates. Acta Biomater. 2017;50:102-113.

45. Liu X, Liu J, Kang N, et al. Role of insulin-transferrin-selenium in auricular chondrocyte proliferation and engineered cartilage formation in vitro. Int J Mol Sci. 2014;15(1):1525-1537.

46. Zhang L, Yang C, Li J, et al. High extracellular magnesium inhibits mineralized matrix deposition and modulates intracellular calcium signaling in human bone marrow-derived mesenchymal stem cells. Biochem Biophys Res Commun. 2014;450(4):1390-1395.

47. Hao B, Webb SE, Miller AL, et al. The role of $\mathrm{Ca}(2+)$ signaling on the self-renewal and neural differentiation of embryonic stem cells (ESCs). Cell Calcium. 2016;59(2-3):67-74. 
48. Veeraraghavan R, Györke S, Radwański PB. Neuronal sodium channels: emerging components of the nano-machinery of cardiac calcium cycling. J Physiol. 2017;595(12):3823-3834.

49. Ahmed ME, Dong Y, Lu Y, et al. Beneficial Effects of a CaMKII $\alpha$ Inhibitor TatCN21 Peptide in Global Cerebral Ischemia. J Mol Neurosci. 2017;61(1):42-51.

50. Menorval MA, Andre FM, Silve A, et al. Electric pulses: a flexible tool to manipulate cytosolic calcium concentrations and generate spontaneous-like calcium oscillations in mesenchymal stem cells. Sci Rep. 2016;6:32331.

51. Kemp PJ, Rushton DJ, Yarova PL, et al. Improving and accelerating the differentiation and functional maturation of human stem cell-derived neurons: role of extracellular calcium and GABA. J Physiol. 2016;594(22):6583-6594.

52. Birgani TZ, Blitterswijk VCA, Habibovic P. Monolithic calcium phosphate/poly(lactic acid) composite versus calcium phosphate-coated poly(lactic acid) for support of osteogenic differentiation of human mesenchymal stromal cells. J Mater Sci Mater Med. 2016;27(3):54

53. Dumont VC, Mansur HS, Mansur AA, $t$ al. Glycol chitosan/nanohydroxyapatite biocomposites for potential bone tissue engineering and regenerative medicine. Int J Biol Macromol. 2016;93(Pt B):1465-1478.

54. Liu X, Liu J, Kang N, et al. Role of insulin-transferrin-selenium in auricular chondrocyte proliferation and engineered cartilage formation in vitro. Int J Mol Sci. 2014;15(1):1525-1537.

55. Bull E, Madani SY, Sheth R, et al. Stem cell tracking using iron oxide nanoparticles. Int J Nanomedicine. 2014;9:1641-1653.

56. Oliveira JM, Kotobuki N, Tadokoro M, et al. Ex vivo culturing of stromal cells with dexamethasone-loaded carboxymethylchitosan/poly(amidoamine) dendrimer nanoparticles promotes ectopic bone formation. Bone. 2010;46(5):1424-1435.

57. Malhotra A, Habibovic P. Calcium Phosphates and Angiogenesis: Implications and Advances for Bone Regeneration. Trends Biotechnol. 2016;34(12):983-992.

58. Orita T, Tomita M, Kato K. Regulation of cellular responses to macroporous inorganic films prepared by the inverse-opal method. Colloids Surf B Biointerfaces. 2011;84(1):187-197.

59. Huang CY, Huang TH, Kao CT, et al. Mesoporous calcium silicate nanoparticles with drug delivery and odontogenesis properties. $J$ Endod. 2017;43(1):69-76.

60. Eapen A, Ramachandran A, George A. Dentin phosphoprotein (DPP) activates integrin-mediated anchorage-dependent signals in undifferentiated mesenchymal cells. J Biol Chem. 2012;287(8):5211-5224.

61. Kaji H. Menin and bone metabolism. $J$ Bone Miner Metab. 2012;30(4):381-387.

62. Marelli B, Ghezzi CE, Alessandrino A, et al. Silk fibroin derived polypeptide-induced biomineralization of collagen. Biomaterials. 2012;33(1):102-108
63. Yuan J, Cao Y, Liu W. Biomimetic scaffolds: implications for craniofacial regeneration. J Craniofac Surg. 2012;23(1):294-297.

64. Luz GM, Mano JF. Biomimetic design of materials and biomaterials inspired by the structure of nacre. Philos Trans A Math Phys Eng Sci. 2009;367(1893):1587-1605.

65. Apáti Á, Berecz T, Sarkadi B. Calcium signaling in human pluripotent stem cells. Cell Calcium. 2016;59(2-3):117-123.

66. Smith KA, Ayon RJ, Tang H, et al. Calcium-Sensing Receptor Regulates Cytosolic [Ca (2+)] and Plays a Major Role in the Development of Pulmonary Hypertension. Front Physiol. 2016;7:517.

67. Supraja A, Dinesh MG, Rajasekaran S, et al. Effect of Cyclosporin A and Angiotensin II on cytosolic calcium levels in primary human gingival fibroblasts. Dent Res J (Isfahan). 2016;13(5):405-412.

68. Zofkova I, Davis M, Blahos J Trace elements have beneficial, as well as detrimental effects on bone homeostasis. Physiol Res. 2017;66(3):391402.

69. Bouillon R. Comparative analysis of nutritional guidelines for vitamin D. Nat Rev Endocrinol. 2017;13(8):466-479.

70. Sato T, Courbebaisse M, Ide N, et al. Parathyroid hormone controls paracellular $\mathrm{Ca} 2+$ transport in the thick ascending limb by regulating the tight-junction protein Claudin14. Proc Natl Acad Sci U S A. 2017;114(16):E3344-E3353.

71. Sherk VD, Wherry SJ, Barry DW, et al. Calcium Supplementation Attenuates Disruptions in Calcium Homeostasis during Exercise. Med Sci Sports Excerc. 2017;49(7):1437-1442.

72. Fleet JC. The role of vitamin D in the endocrinology controlling calcium homeostasis. Mol Cell Endocrinol. 2017;453:36-45.

73. Insua A, Monje A, Wang HL, Miron RJ. Basis of bone metabolism around dental implants during osseointegration and peri-implant bone loss. J Biomed Mater Res A. 2017;105(7):2075-2089.

74. Sarode GS, Sarode SC, Patil S. Multifaceted Role of Calcium in Cancer J Contemp Dent Pract. 2017;18(1):1-2.

75. Nakashima T. Bone homeostasis and Mechano biology. Clin Calcium 2016;26(12):1685-1695.

76. An J, Hao D, Zhang Q, et al. Treatment of bone erosive diseases: The effects and mechanisms on inhibiting osteoclastogenesis and bone resorption. Int Immunopharmacol. 2016;36:118-131.

77. Branstetter JG, Jackson SR, Haggard WO, et al. Locally-administered antibiotics in wounds in a limb. J Bone Joint Surg Br. 2009;91(8):11061109.

78. Klein MO, Kämmerer PW, Scholz T, et al. Modulation of platelet activation and initial cytokine release by alloplastic bone substitute materials. Clin Oral Implants Res. 2010;21(3):336-345. 